\title{
Second species of Mangkurtu (Spelaeogriphacea) from north-western Australia
}

\author{
Gary C. B. Poore ${ }^{1}$ and W. F. Humphreys ${ }^{2}$ \\ 'Museum Victoria, PO Box 666E, Victoria 3001, Australia \\ email: gpoore@museum.vic.gov.au \\ ${ }^{2}$ Western Australian Museum, Francis Street, Perth, Western Australia 6000, Australia \\ email: humphw@museum.wa.gov.au
}

\begin{abstract}
A new species, Mangkurtu kutjarra, is described, the second in this genus from Australia, and fourth living in the Order Spelaeogriphacea in the world. It occurs in a calcrete aquifer very close to that in which its congener lives in the Pilbara, Western Australia. Spelaeogriphacea, like Thermosbaenacea are thought to be relicts of a more widespread shallowwater marine Tethyan fauna stranded in interstitial or ground-water environments during periods of marine regression.
\end{abstract}

\section{INTRODUCTION}

Over the last few years an extraordinary diversity of stygal animals has been recorded from arid parts of Western Australia occupying both anchialine ecosystems and continental groundwaters (Humphreys, 1999, 2001), both fresh and saline. As is the case globally, these species largely comprise crustaceans, but a diversity of dytiscid beetles (Cooper et al., 2002; Watts and Humphreys, 1999) and hydrobiid gastropods is also notable.

Amongst this fauna, Mangkurtu mityula Poore and Humphreys, 1998, from the Millstream (Western Fortescue Plain) aquifer in the Pilbara, was the first record of Spelaeogriphacea from Australia. This order was first described (Spelaeogriphus lepidops Gordon, 1957) from a sandstone cave at an altitude of $700 \mathrm{~m}$ on Table Mountain, South Africa. This remained the only record until another member of the order was found in a cave in the Mato Grosso in western Brazil (Potiicoara brasiliensis Pires, 1987). The Millstream species is the only species known to be widely present in a major aquifer where it is found together with a range of other Gondwanan freshwater lineages (Poore and Humphreys, 1998). The occurrence of fossil species of purported spelaeogriphaceans, Acadiocaris novascotica (Copeland, 1957) in Carboniferous marine sediments in Canada (Schram, 1974), and in lacustrine deposits of Jurassic age in China (Lianongogriphus quadripartitus Shen et al., 1998) suggests that invasion of fresh water occurred prior to the dissolution of Pangaea and long before the fragmentation of Gondwana (Poore and Humphreys, 1998).

A Tethyan fauna, allied to the stygofauna of the Cape Range peninsula and Barrow Island
(Humphreys, 2000), intrudes towards Millstream from the coast and is present in aquifers of the lower reaches of the Robe and Fortescue Rivers. Elements of this fauna reach an altitude of c. $300 \mathrm{~m}$ in the Robe River (Humphreys, 2001), the approximate level of the Late Eocene sea-level high in south-western Australia (G.W. Kendrick, personal communication 1999).

Here, a second species of the Australian genus is described from material collected in the same region as the first. Its environment is described. Sampling was conducted and water quality measured as detailed elsewhere (Watts and Humphreys, 2000). Material is lodged in the Western Australian Museum, Perth (WAM) and Museum Victoria, Melbourne (NMV).

\section{Order Spelaeogriphacea Gordon, 1957}

Family Spelaeogriphidae Gordon, 1957

\section{Mangkurtu Poore and Humphreys, 1998}

\section{Remarks}

Mangkurtu is unique among spelaeogriphacean genera in the possession of a digitiform maxillipedal epipod and in having endopodal lobes on the pleopods. The new species is similar in these respects and in many others to $M$. mityula, type species, but differs in the proportions and shapes of some morphological features. We do not reillustrate mouthparts but microscopic examination and SEMs provided to us by G.D.F. Wilson show no important differences. Mangkurtu is the only spelaeogriphid genus with more than one species.

In Poore and Humphreys' (1998) diagnoses of the 
three extant genera the length of the antennal 2 scale was compared to peduncular article 3 . It is now apparent that this "article 3 " is in fact articles 3 and 4 together. No authors, including ourselves, have illustrated the very short article 3 of spelaeogriphaceans and have treated the antenna 2 peduncle as having four articles. We were able to confirm a similar very short article 3 visible only ventrally in a specimen of Spelaeogriphus. Spelaeogriphaceans have five antennal articles like all eumalacostrans (Figure 1c). We are now able to confirm that oostegites occur on pereopods 1-5 on this species as in other spelaeogriphaceans. Juveniles of the new species possess a reduced pereopod 7 (Figure 1e) and we assume that this manca stage, hitherto unreported, is general for spelaeogriphaceans. Embryos flex dorsally.

Gordon's (1957) figures of maxilla 2 of Spelaeogriphus lepidops suggest a pattern of setation on the outer endites different from that in Mangkurtu. We were able to observe that the triangular setae drawn by her are in fact just the tips of much longer curved setae, similar to those seen in the other genera.

\section{Mangkurtu kutjarra sp. nov. Figures 1-3}

\section{Material examined}

\section{Holotype}

Western Australia. Pilbara Region, Fortescue River Valley, Roy Hill Station, Battle Hill Well, $22^{\circ} 44^{\prime} 28^{\prime \prime} S$, $120^{\circ} 07^{\prime} 37^{\prime \prime}$ E, W.F. Humphreys and J.M. Waldock, 8 September 2000 (stn BES 8505), WAM C29101 (male, $4.5 . \mathrm{mm}$, with 5 slides).

\section{Paratypes}

Collected with holotype, WAM C29102 (female with oostegites, $4.5 \mathrm{~mm}$ ) C29103 (female with oostegite buds, $3.6 . \mathrm{mm}$, with 3 slides), C29104 (juvenile, 4.0.mm), C2915 ( 2 males, $4.0,4.6 \mathrm{~mm}$ ), C29106 (female with oostegites and 16 eggs), C29107 (4 females, incomplete), C29108 (20 juveniles and mancas, incomplete); NMV J57461 (male), J57462 (male, $4.5 \mathrm{~mm}$ ), J57463 (female with oostegite buds, $3.6 \mathrm{~mm}$ ), J57464 (male, $4.2 \mathrm{~mm}$ ), J57465 (male, $4.2 \mathrm{~mm}$ ), J57466 (juvenile). Same area and date, Aerodrome Bore, $22^{\circ} 42^{\prime} 53^{\prime \prime} \mathrm{S}, 119^{\circ} 54^{\prime} 53^{\prime \prime} \mathrm{E}$ (stn BES 8501), NMV J57467 (male, 2 females, 2 juveniles).

\section{Description}

Male. Ratio of carapace : pereon : pleon ratio 1 : 1.9 : 3.2. Telson 1.2 times as long as wide at base, tapering to semicircular apex with three pairs of marginal spiniform setae, first pair (most lateral) the longest; and 1 shorter pair submarginal-dorsal between 2 most lateral setae.

Antenna 1 total length 0.65 of body; outer flagellum with c. 37 articles; inner flagellum of 30 articles.

Antenna 21.5 times length of body; peduncle article 2 with distolateral row of stout setae; article 3 very short; article 4 longer than article 2; article 5 longer than 4 , with distal setae; exopod width 0.30 length, with medial rows of alternating eight plumose and eight stout setae.

Pereopods 1-7 similar to those of M. mityula, endopod and exopods of similar proportions, bases of 5-7 with similar pedunculate setae. Distal margins of carpi of all pereopods with oblique row of falcate setae mounted on conical projections: nine or ten on pereopods 1-3, four-seven on pereopod 4; propodi with groups of one-three similar setae.

Penes at bases of pereopods 7 cylindrical, stout, meeting in midsternum.

Pleopod 2 exopod two-articulate, shorter than endopod; proximal article with one lateral simple seta, one distolateral plumose and one distomesial plumose setae; distal article with 18 marginal plumose setae and 13 shorter simple setae on distal margin; endopod broadly-falcate, curving laterally to enclose exopod, with one proximomesial and 4 midmesial setae.

Uropod peduncle with four distolateral, 2 distomesial, one proximomesial spiniform setae, one simple and one plumose setae ventrally on distal margin; endopod with 22 marginal plumose setae and two or three submarginal dorsal setae; exopod two-articulate; proximal article longer than endopod, with four distolateral, six mesial spiniform setae; distal article twice as long as wide, with 26 marginal plumose setae, one simple apical setae.

Manca. Pereonite 7 apparent as a single article.

Ovigerous female. Ratio of carapace : pereon : pleon ratio $1: 2.5: 2.7$. Pleopod 2 similar to pleopods 1 and 3; oostegites on pereopods 1-5, carrying in one case 16 eggs and in another four embryos. Embryos flex dorsally.

\section{Etymology}

Kutjarra, meaning two in the Australian Aboriginal language of the Western Desert, alluding to the second species in the genus.

\section{Distribution}

Roy Hill calcrete, Pilbara, Western Australia.

\section{Remarks}

Mangkurtu kutjarra differs from $M$. mityula in the shape of the telson (more tapered and with a more rounded apex, four rather that five pairs of distal marginal setae), proportions of the uropod (endopod shorter and relatively wider, with more 


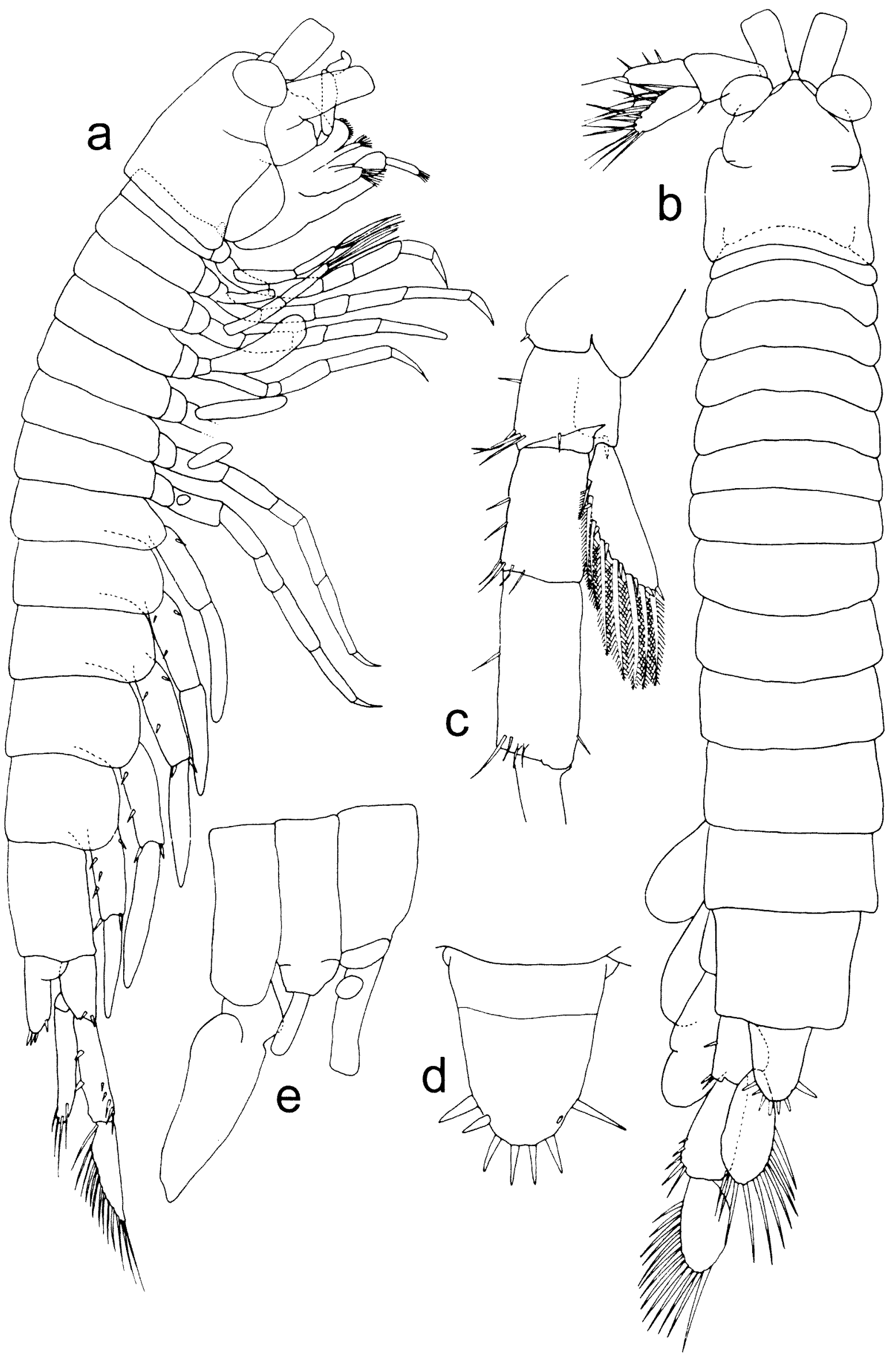

Figure 1 Mangkurtu kutjarra n. sp. Holotye male, $4.5 \mathrm{~mm}$, WAM C29101. a, b, habitus (scale $0.5 \mathrm{~mm}$ ); $\mathrm{c}$, antenna 2 peduncle; d, telson. Manca, WAM C29108. e, (right to left) pereonites 6 and 7, pleonite 1 with basis of pereopod 6 , pereonite 7 , and peduncle of pleopod 1 . 


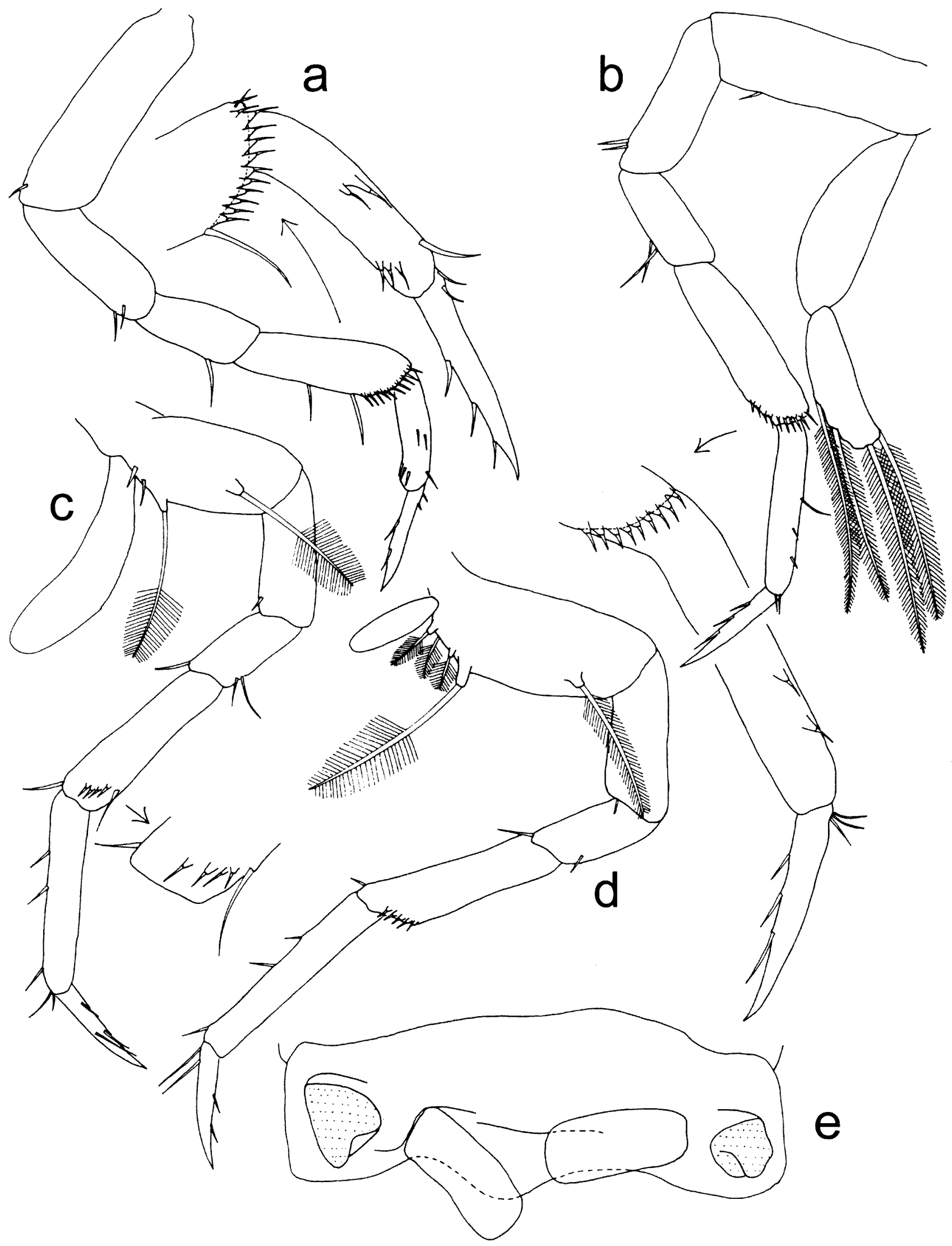

Figure 2 Mangkurtu kutjarra n. sp. Holotype male, $4.5 \mathrm{~mm}$, WAM C29101. a-d, pereopods 1, 2, 4 and 6 with details of distal articles; e, ventral view of pereonite 7 with penes. 

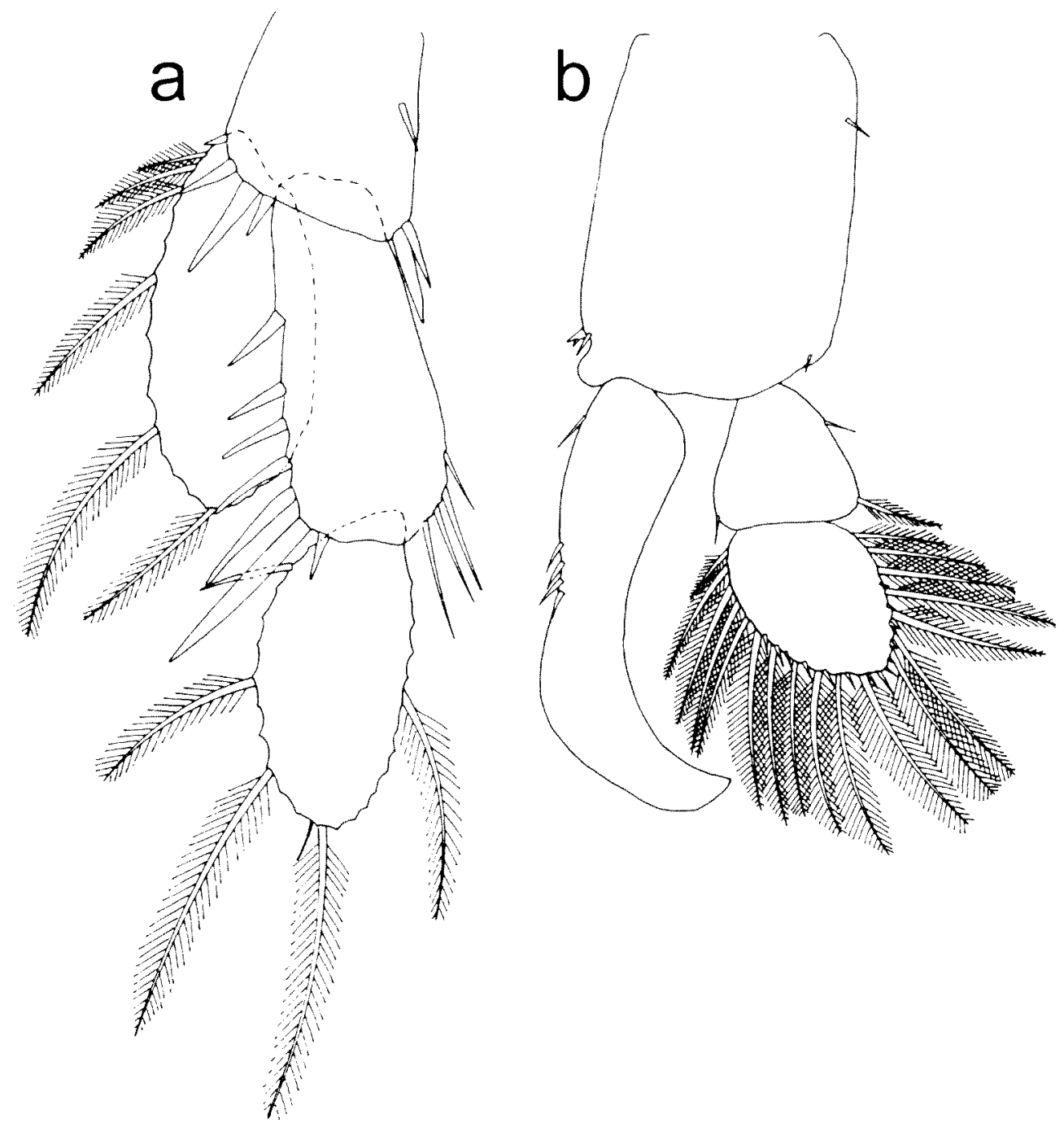

Figure 3 Mangkurtu kutjarra n. sp. Holotype male, 4.5 mm, WAM C29101. a, uropod; b, pleopod 2.

setae), and shape of the male pleopod 2 endopod (much more curved and broader).

\section{The environment}

The Fortescue Valley extends for $450 \mathrm{~km}$ as a broad plain trending west-north-west between the Hamersley and Chichester Ranges in the Pilbara, the northern craton of the 'Western Shield' of Australia. The upper part of the river and its tributaries drain the Archaean ranges to the Cainozoic surficial alluvial deposits in the Fortescue Valley.

The Fortescue Valley contains several discrete groundwater calcrete deposits, the larger being those at Roy Hill and the Western Fortescue Plain (Millstream, a lacustrine calcrete of Tertiary age)the nature of these calcretes is discussed elsewhere in the context of stygofauna (Humphreys, 1999; 2001). Further calcrete bodies occur downstream of Roy Hill, successively at Mulga Downs, Mount Florance and Millstream, the latter being the habitat of Mangkurtu mityula, before the river descends through groundwater gaps to the coastal plain.
Sampling has not detected spelaeogriphaceans in the Mulga Downs and Mount Florance calcretes, although other stygofauna do occur there.

Mangkurtu kutjarra occurs in a groundwater calcrete aquifer on Roy Hill pastoral station in the upper Fortescue Valley (Figure 4), immediately upstream of the Fortescue Marsh which generally comprises a salt lake (playa). The Fortescue Marsh is now an internal drainage basin within the Fortescue palaeodrainage and even in times of peak flow - following rare episodic rainfalls, when an extensive lake may form lasting many months to several years - it does not discharge downstream. Consequently, the area accumulates salt from aerial deposition and contains hypersaline groundwater. Floods that do recharge the Millstream aquifer downstream result from flows of the South Fortescue River. Hence, the Millstream aquifer is now probably isolated from those upstream in the Fortescue Valley, including the Roy Hill calcrete. In the Eocene the Fortescue Marsh drained externally through the current Robe River and a variety of evidence, though not conclusive, suggests that the 


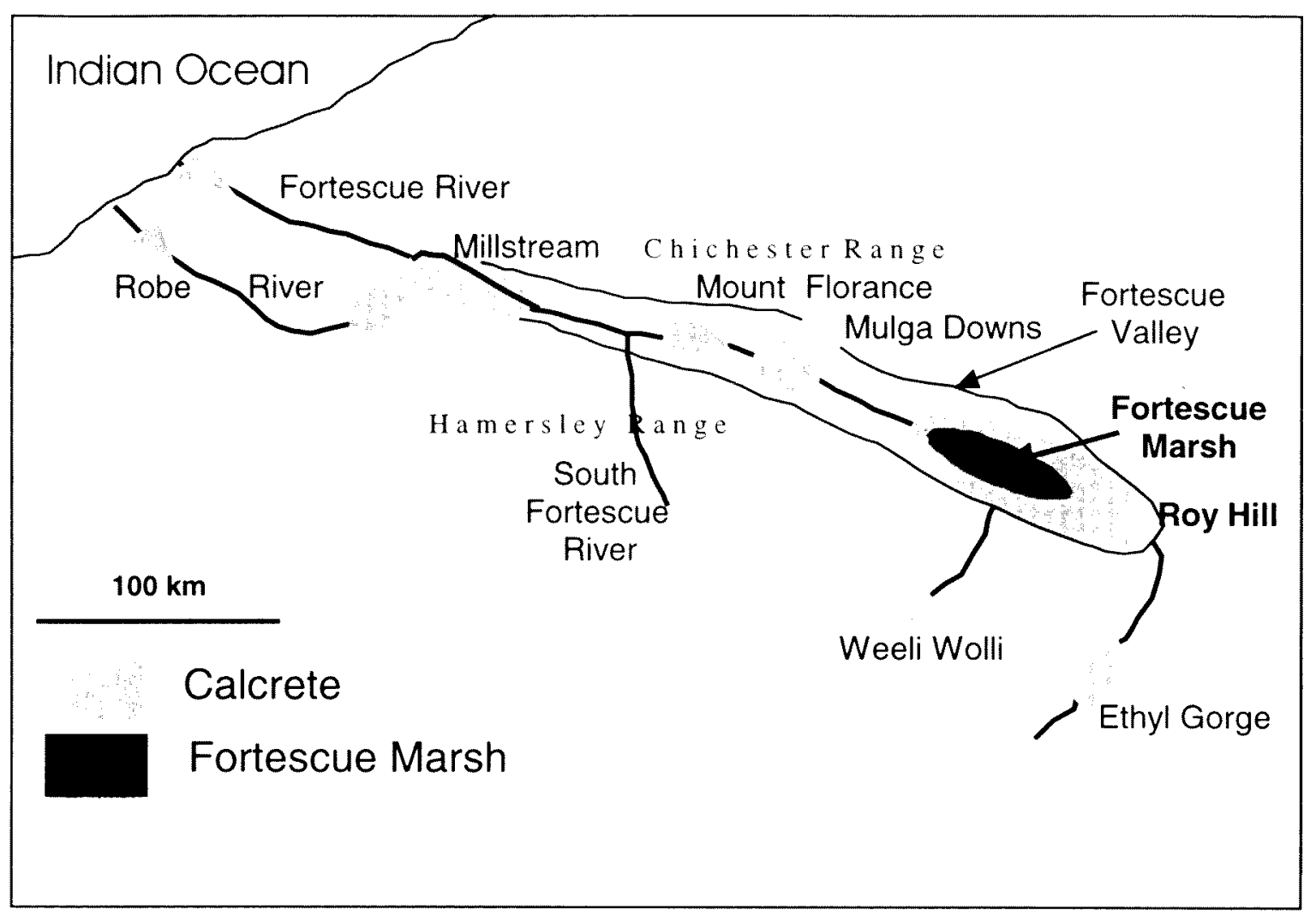

Figure 4 Schematic diagram of the Fortescue Valley and the spatial relationship of the Roy Hill calcrete area to other calcretes in the drainage system and the Fortescue Marsh.

Marsh could have been essentially internally draining since the Miocene. However, the groundwater system is still continuous and the amount of salt in the hypersaline groundwater in the Marsh suggests that there have been exceptional wet periods in which the marsh overflowed to the west (D.P. Commander, personal communication 2003).

The water inhabited by Mangkurtu kujarra is slightly saline and with low oxygen saturation but with a pH typical of calcrete areas (Table 1). It is not known whether the water column is highly stratified with respect to salinity as found in some other arid areas of Western Australia (Watts and Humphreys, 2000; Humphreys, 2002).

\section{BIOGEOGRAPHIC AND CONSERVATION IMPLICATIONS}

The presence of isolated populations of separate species of spelaeogriphaceans suggests that the groundwater calcrete deposits have long been separated from each other. Similar speciation is seen amongst stygal Dytiscidae (Insecta: Coleoptera) in the Yilgarn (the southern part of the Western Shield) where both morphological and molecular evidence support the thesis that the calcretes form separate islands of groundwater,
Table 1 Site description and water quality at two collection sites from which $M$. kutjarra was taken at Roy Hill Station, Fortescue River Valley, Pilbara Region, WA.

\begin{tabular}{lcc}
\hline Parameter & $\begin{array}{c}\text { Battle Hill } \\
\text { Well }\end{array}$ & $\begin{array}{c}\text { Aerodrome } \\
\text { Bore }\end{array}$ \\
\hline Site description & $\begin{array}{c}\text { Well maintained, } \\
\text { uncovered, cement- } \\
\text { lined well on raised } \\
\text { stone plinth }\end{array}$ & $\begin{array}{c}\text { Overgrown, } \\
\text { open borehole, } \\
\text { fetid }\end{array}$ \\
Conductivity $\left(\mathrm{mS} \mathrm{cm}^{-1}\right)$ & 6.65 & \\
Salinity $\left(\mathrm{g} \mathrm{L}^{-1}\right)$ & 3.94 & 5.67 \\
Temperature $\left({ }^{\circ} \mathrm{C}\right)$ & 25.5 & 3.36 \\
$\mathrm{O}_{2}$ (mg L $\left.\mathrm{L}^{-1}\right)$ & 1.5 & 29.2 \\
$\mathrm{O}_{2}$ saturation $(\%)$ & 18.6 & 0.71 \\
pH & 7.13 & 9.2 \\
Depth to water $(\mathrm{m})$ & 3.6 & 7.20 \\
Depth of water $(\mathrm{m})$ & 4.0 & 9 \\
\hline
\end{tabular}

many containing a unique fauna (Watts and Humphreys, 1999, 2000, 2001; Cooper et al., 2002). This appears to be the case there also with stygal Haloniscus (Crustacea: Isopoda: Oniscidea) which occurs as sympatric congeners (Taiti and Humphreys, 2001).

The Fortescue calcrete aquifers contain numerous new genera and species of Candoninae (Crustacea: 
Ostracoda): one an undescribed genus from the Roy Hill calcrete as yet unknown elsewhere, others species from the calcretes upstream (Ethyl Gorge) representing two different undescribed genera, while a further two undescribed genera occur downstream of Roy Hill, from Mulga Downs to the coast. Furthermore, a tributary joining the central Fortescue Marsh (Weeli Wolli Creek) contains a further two undescribed genera (I. Karanovic, personal communication). In addition, isopods of the genus Pygolabis, second genus of the enigmatic family Tainisopidae first described from the Kimberley (Wilson and Ponder, 1992), are represented by at least four species (Wilson, 2003) in separate calcretes found in drainages to the main Fortescue Valley.

The occurrence of distinct faunas in the discrete deposits of groundwater calcrete on the Western Shield has become contentious owing to the conservation implications of numerous discrete faunas in shallow unconfined groundwaters in an arid but mineraliferous region. For example, numerous species of Chydaekata (Amphipoda: Paramelitidae) have been described from the calcretes of the upper Fortescue River, at Ethyl Gorge (Bradbury, 2000) but thus far these have not been corroborated by electrophoretic data. Among the diverse copepod fauna of the Yilgarn (Karanovic, in press), many species have quite widespread distributions, not being confined to single calcretes. It is not unexpected to find a diversity of responses amongst lineages of different ages and ecologies in response to the evolution of this ancient landscape.

\section{Biogeographic implications}

Present-day Thermosbaenacea (which comprise only 34 species in total) are thought to be relicts of a more widespread shallow-water marine Tethyan fauna (Wagner, 1994), stranded in interstitial or ground-water environments during periods of marine regression. The same hypothesis has been applied to other taxa such as stygiobiont Amphipoda (Stock, 1993) and the copepod genus Misophriopsis (Boxshall and Jaume, 2000). This hypothesis can be extended to the four spelaeogriphacean species and the existence of a supposed marine fossil, Acadiocaris novascotica (Copeland, 1957) from the Carboniferous in Canada (Schram, 1974), gives some support.

This is consistent with the intrusion of Tethyan fauna, especially Halosbaena tulki (Thermosbaenacea), up the Robe River, the fomer Fortescue drainage and close to Mangkurtu mityula sites, to an altitude of c. $300 \mathrm{~m}$ (Humphreys, 2001), the approximate level of the Late Eocene sea-level high in south-western Australia (G.W. Kendrick, personal communication 1999). However, the three extant genera of Spelaeogriphacea all occur on parts of the continents that have not been inundated by the sea since the dissolution of Gondwana, which commenced with the separation of east- and westGondwana (142-133 Ma: Partridge and Maud, 1987). Each species now occurs with a very circumscribed distribution in subterranean freshwater habitats on Gondwanan fragments (Africa, South America and Australia) (Poore and Humphreys, 1998). While both Mangkurtu and Spelaeogriphus locations may have abutted the shoreline of Cretaceous or Late Jurassic marine incursions (Scotese, 1998), such proximity in the case of Potiicoara in the southern Mato Grosso, Brazil, is obscure. The sites lie in an extensive karst area cut by the Rio Paraguai valley at an altitude of only c. $330 \mathrm{~m}$, despite lying nearly $1000 \mathrm{~km}$ inland, and the cave waters inhabited descends about 200 $m$ (Moracchioli, 2002). Hence the area may have abutted Eocene shores and a clear marine intrusion into the region in the Late Miocene (10 Ma) and less clearly in the Palaeocene $(60 \mathrm{Ma})$ directly from western Tethys was shown by Smith et al. (1994).

\section{ACKNOWLEDGEMENTS}

We thank the lessees of the pastoral stations for facilitating access and Julianne Waldock for wonderful support in the field and the laboratory. For specimens of the extant non-Australian Spelaeogriphacea we thank Nicoletta Moracchioli and Norma Sharratt. We thank G.D.F. (Buz) Wilson, Australian Museum, Sydney for allowing us to see the SEMs prepared by him. Field work was funded by the BankWest Landscape Conservation Visa Card Trust Fund Grants.

\section{REFERENCES}

Boxshall, G.A. and Jaume, D. (2000). Discoveries of cave misophioirds (Crustacea: Copepoda) shed new light on the origin of anchialine faunas. Zoologischer Anzeiger 239: 1-19.

Bradbury, J.H. (2000). Western Australian stygobiont amphipods (Crustacea: Paramelitidae) from the $\mathrm{Mt}$ Newman and Millstream regions. Records of the Western Australian Museum, Supplement 60: 1-102.

Cooper, S., Hinze, S., Leys, R., Watts, C.H.S. and Humphreys, W.F. (2002). Islands under the desert: molecular systematics and evolutionary origins of stygobitic water beetles (Coleoptera: Dytiscidae) from central Western Australia. Invertebrate Systematics 16: 589-598.

Copeland, M.J. (1957). The Carboniferous genera Palaeocaris and Euproops in the Canadian maritime provinces. Journal of Paleontology 31: 595-99.

Gordon, I. (1957). On Spelaeogriphus, a new cavernicolous crustacean from South Africa. Bulletin of the British Museum of Natural History (Zoology) 5: 31-47.

Humphreys, W.F. (1999). Relict stygofaunas living in sea salt, karst and calcrete habitats in arid northwestern 
Australia contain many ancient lineages. In: Ponder, W.F., and Lunny, D. (eds), The other 99\%. The conservation and biodiversity of invertebrates. Royal Zoological Society of New South Wales, Mossman. Pp. 219-227.

Humphreys, W.F. (2000). The hypogean fauna of the Cape Range peninsula and Barrow Island, northwestern Australia. In: Wilkins, H., Culver, D.C., and Humphreys, W.F. (eds), Ecosystems of the World. Elsevier, Amsterdam. Pp. 581-601.

Humphreys, W.F. (2001). Groundwater calcrete aquifers in the Australian arid zone: the context to an unfolding plethora of stygal biodiversity. In: Humphreys, W.F. and Harvey, M. S. (eds), Subterranean Biology in Australia 2000. Records of the Western Australian Museum, Supplement 64: 63-83.

Humphreys, W.F. (2002). Groundwater ecosystems in Australia: an emerging understanding. Proceedings of the International Association of Hydrogeologists Conference, Darwin, Australia 12-17 May 2002. CDROM.

Karanovic, T. (in press). Subterranean copepods (Crustacea: Copepoda) from arid Western Australia. Crustaceana Monographs 3.

Moracchioli, N. (2002). Estudo dos Spelaeogriphacea brasileiros, crustáceos Peracarida subterrâneos. Doutor em Ciências thesis, Instituto de Biociências da Universidade de São Paulo, São Paulo.

Partridge, T.C. and Maud, R.R. (1987). Geomorphic evolution of southern Africa since the Mesozoic. South African Journal of Geology 90: 179-208.

Pires, A.M.S. (1987). Potiicoara brasiliensis: a new genus and species of Spelaeogriphacea (Crustacea: Peracarida) from Brazil with a phylogenetic analysis of the Peracarida. Journal of Natural History 21: 225238.

Poore, G.C.B. and Humphreys, W.F. (1998). First record of Spelaeogriphacea from Australasia: a new genus and species from an aquifer in the arid Pilbara of Western Australia. Crustaceana 71: 721-742.

Schram, F.R. (1974). Paleozoic Peracarida of North America. Fieldiana Geology 33: 95-124.
Scotese, C.R. (1998) Paleogeographic Atlas. PALEOMAP Project. University of Texas, Arlington.

Shen, Y.-b., Taylor, R.S. and Schram, F.R. (1998). A new spelaeogriphacean (Crustacea: Peracarida) from the Upper Jurassic of China. Contributions to Zoology 68: 19-35.

Smith, A.G., Smith, D.G. and Funnell, B.M. (1994). Atlas of Mesozoic and Cenozoic coastlines. Cambridge University Press, Cambridge.

Stock, J.H. (1993). Some remarkable distribution patterns in stygobiont Amphipoda. Journal of Natural History 27: 807-819.

Taiti, S. and Humphreys, W.F. (2001). New aquatic Oniscidea (Crustacea: Isopoda) from groundwater calcretes of Western Australia. Records of the Western Australian Museum, Supplement 64: 133-151.

Wagner, H.P. (1994). A monographic review of the Thermosbaenacea (Crustacea: Peracarida). Zoologische Verhandelingen, Leiden 291: 1-338.

Watts, C.H.S. and Humphreys, W.F. (1999). Three new genera and five new species of Dytiscidae (Coleoptera) from underground waters in Australia. Records of the South Australian Museum 32: 121-142.

Watts, C.H.S. and Humphreys, W.F. (2000). Six new species of Nirridessus and Tjirtudessus (Dytiscidae; Coleoptera) from underground waters in Australia. Records of the South Australian Museum 33: 127-144.

Watts, C.H.S. and Humphreys, W.F. (2001). A new genus and six new species of Dytiscidae (Coleoptera) from underground waters in the Yilgarn palaeodrainage system of Western Australia. Records of the South Australian Museum 34: 99-114.

Wilson, G.D.F. (2003). A new genus of Tainisopidae fam. nov. (Crustacea: Isopoda) from the Pilbara, Western Australia. Zootaxa 245: 1-20.

Wilson, G.D.F. and Ponder, W.F. (1992). Extraordinary new subterranean isopods (Peracarida: Crustacea) from the Kimberley region, Western Australia. Records of the Australian Museum 44: 279-298.

Manuscript received 23 April 2003; accepted 18 June 2003 